\title{
PEDAGOGICKO-PSYCHOLOGICKÁ PORADENSKÁ PÉČE V ČESKÉ REPUBLICE A VELKÉ BRITÁNII
}

\author{
TEREZA KOLEČKOVÁ
}

\begin{abstract}
Abstrakt: Článek srovnává pedagogicko-psychologickou poradenskou péči v České republice a Velké Británii. Již na konci 19. století se v některých státech začaly objevovat první laboratoře, které poskytovaly rady při výchově a vzdělávání studentů. Po první světové válce se mezi ně zařadilo i tehdejší Československo. Text předkládá a popisuje dva typy poradenských zařízení v České republice, a také stř̌ediska výchovné péče. Dále článek seznamuje s poradenstvím, tzv. counselling a poradenstvím pro žáky se speciálně vzdělávacími potřebami ve Velké Británii. V závěru článku je popsaná osobní zkušenost ze stáže v Brighton Metropolitan College a jejich možnost poskytování poradenské péče. Klíčová slova: poradenství, pedagogicko-psychologická poradna, speciálně pedagogické centrum, counselling, psychologická péče
\end{abstract}

Pedagogical-psychological counselling care in the Czech Republic and Great Britain Abstract: The article compares pedagogical-psychological counselling care in the Czech Republic and Great Britain. As early as the end of the 19th century, the first laboratories began to appear in some states to provide advice on the education and training of students. After the First World War, the then Czechoslovakia also joined them. The text presents and describes two types of counselling facilities in the Czech Republic, as well as educational care centers. It also introduces counselling and counselling for pupils with special educational needs in the UK. The article concludes with a description of personal experience from an internship at Brighton Metropolitan College and their ability to provide counselling care.

Keywords: counselling, pedagogical-psychological counselling, special pedagogical center, psychological care

https://doi.org/10.14712/23366486.2021.2

\section{Úvod}

Pedagogicko-psychologická poradenská péče má své začátky již v roce 1884 , kdy Francis Galton otevřel v Anglii antropometrickou laboratoř. Jejím cílem bylo poskytovat rady při výchově dětí rodinám a školám. Následně se otevřela první poradenská klinika v USA při Pensylvánské univerzitě v roce 1896. Již v té době byly snahy o nápravy poruch pravopisu. V roce 1905 byla založena pedagogická laboratoř ve Francii Alfredem Binetem. Významný je také vznik první specializované poradny pro volbu povolání v roce 1908 v Bostonu. Dále v roce 1909 byla zrrízena první vysokoškolská poradna na Harvardské univerzitě. První česká poradna pro volbu povolání byla otevřena 15. 11. 1919 při českém odboru Zemské rady živnostenské v Brně a byla spojovaná s významným pedagogem 
a psychologem Otakarem Chlupem. V roce 1920 vznikla první poradna v Praze při Zemské centrále práce. Zajímavý je také začátek ústředních poraden pro volbu povolání v Bratislavě v roce 1928, za kterým stál Josef Stavěl. Vývoj poraden pro volbu povolání byl v období od druhé světové války až do roku 1957 přerušen. Poté začaly vznikat dětské psychologické poradny a psychologické výchovné poradny a kliniky. V roce 1972 se poprvé v české terminologii objevuje výraz pedagogicko-psychologická poradna (Kohoutek, 1998).

V roce 1990 začala vznikat speciálně pedagogická centra, která se zaměřovala na péči o děti se smyslovým, tělesným a mentálním postižením a dále o děti s vadami řeči. V neposlední řadě je důležité také zmínit, že ve stejném období byla zřízena střediska výchovné péče, která zajišt'ují prevenci a terapii sociálně patologických jevů u dětí a mládeže (Kohoutek, 1998).

\section{Pedagogicko-psychologická poradenská péče v České republice}

V České republice existují dva typy poradenských zařízení - školská poradenská zařízení a školní poradenská pracoviště. Školská poradenská zařizení (ŠPZ) tvoří pedagogicko-psychologické poradny a speciálně pedagogická centra (ŠPZ, n.d.). Školní poradenská pracoviště (ŠPP) poskytují poradenské služby př́mo ve škole. Jejich cílem je výchovná a preventivní oblast školy. Základní povinná část tohoto týmu je ředitel školy, výchovný poradce, školní metodik prevence a učitelský sbor. Dále pak může na školách poskytovat svoje služby školní psycholog a speciální pedagog (Školní poradenské pracoviště, 2018). Shrnutí je uvedeno v tabulce 1 .

Tabulka 1 Shrnuti poradenských služeb ve školství

\begin{tabular}{|c|c|}
\hline Školská poradenská zařízení (ŠPZ) & Školní poradenské pracoviště (ŠPP) \\
\hline pedagogicko-psychologické poradny (PPP) & výchovný poradce (ze zákona povinné) \\
\hline \multirow[t]{3}{*}{ speciálně pedagogická centra (SPC) } & metodik prevence (ze zákona povinné) \\
\hline & školní speciální pedagog \\
\hline & školní psycholog \\
\hline
\end{tabular}

Školská poradenská zařízení poskytují poradenské služby prostřednictvím psychologů, speciálních pedagogů, sociálních pracovníků a v PPP i metodiků prevence. Činnost těchto pracovišs' je zajištěna ambulantně na jednotlivých pracovištích a návštěvami zaměstnanců ve školách a školských zařízeních (Vyhláška č. 197/2016, 2016). SPC mohou navštěvovat klienty i v domácím prostředí (ŠPZ, n.d.). Zařízení obvykle zajišt’ují psychologickou a speciálně pedagogickou diagnostiku v individuální i skupinové podobě, konzultační a poradenskou podporu, vydávají zprávy a doporučení, poskytují metodickou podporu škole a mnoho dalšího (Vyhláška č. 197/2016, 2016). Služby jsou poskytovány bezplatně a jsou určené pro klienty v SPC od 3 do 19 let a v PPP od 3 let do ukončení středního, resp. vyššího odborného vzdělání (ŠPZ, n.d.).

Pedagogicko-psychologická poradna napomáhá žákům se speciálními vzdělávacími potřebami při vytváření podmínek ve vzdělávání především prostřednictvím 
tzv. podpůrných opatření a přispívá žákům s mimořádným nadáním k rozvoji jejich intelektuálních předpokladů či uměleckých vloh (Jedlička, Kot’a a Slavík, 2018). Např. pedagogicko-psychologická poradna na Praze 9 uvádí, že mezi hlavní činností poradny jsou v předškolním věku adaptační potíže při nástupu do MŠ, výchovné obtíže a posouzení školní zralosti. Na základní škole se řeší výchovné a adaptační problémy, dodatečné odklady školní docházky, výukové potíže a speciálně vzdělávací potřeby (poruchy učení, poruchy pozornosti a jiné), problémy ve školní třídě (klima třídy, vztahy mezi žáky) a volba dalšího studijního zaměření. Na střední škole se pak jedná o stejné oblasti jako na základní škole a navíc možnost úpravy podmínek k vykonání maturitní zkoušky. Dále poradna nabízí mnoho dalších programů a pravidelná setkání pro pedagogické pracovníky (PPP 9, n.d.). V celé republice je zhruba 150 pedagogicko-psychologických pracovišt', většina z nich je zřizována krajskými úřady, dále se můžeme setkat se soukromými a církevními pracovišti (Jedlička, Kot’a a Slavík, 2018).

Speciálně pedagogická centra poskytují poradenské služby zejména při výchově a vzdělávání žáků s mentálním, tělesným, zrakovým nebo sluchovým postižením, vadami řeči, souběžným postižením více vadami nebo autismem (Vyhláška č. 197/2016, 2016). Celkový počet SPC je kolem 220 v celé republice, v jednotlivých krajích je počet různý (Speciálně pedagogická centra, 2018).

Školní poradenské pracoviště je zřizováno přímo ve školách a slouží k poskytování poradenských a konzultačních služeb pro žáky, zákonné zástupce a pedagogické pracovníky. Za poskytování služeb zodpovídá ředitel školy (Zapletalová, n.d.).

Výchovný poradce je učitelem a zároveň poradenským pracovníkem. Jeho práce je legislativně vymezena a jsou stanoveny požadavky na jeho vzdělání (Knotová, 2014). Mezi jeho činnosti patří poradenská, metodická a informační činnost, především pak kariérové poradenství, vyhledávání žáků, jejichž vzdělávání vyžaduje zvláštní pozornost, zajišt’ování diagnostiky pro žáky se speciálními vzdělávacími potřebami, příprava podmínek pro integraci žáků, metodická pomoc pedagogickým pracovníkům a mnoho dalšího (Hlad'o, 2012).

Školní metodik prevence obstarává metodickou a koordinační činnost v rámci prevence rizikového chování. Zvyšuje všeobecnou informovanost rodičů, učitelů a žáků při prevenci těchto jevů. Spolupracuje s učiteli a buduje zdravé klima ve tř́dě i ve škole (Geisslerová, 2012). Školním metodikem prevence může být zvolený jakýkoliv učitel, který splňuje kvalifikaci pro výkon funkce (Knotová, 2014).

Školní psycholog poskytuje individuální a skupinovou psychologickou diagnostiku, individuální psychologickou intervenci, dále se věnuje poruchám učení a chování, zabývá se vztahovými problémy, prevencí (i neprospěchu) a prací se třídami. Školní psycholog také zajišt'uje kariérové poradenství (Hlad'o, 2012).

Školni speciálni pedagog má v evidenci děti se speciálními vzdělávacími potřebami. Aktivně spolupracuje s třídními učiteli již od zápisu a dochází na pravidelné návštěvy do tříd. Rozpoznává děti, kterým je potřeba zajistit podporu formou individuální práce (Krejčová a kol., 2018). 
V neposlední řadě je potřeba zmínit stř̌edisko výchovné péče, které zajišt'uje preventivně-výchovnou péči o žáky s rizikem vzniku a vývoje poruch chování (Střediska výchovné péče, n.d.). Cílem je předcházet vzniku a rozvoji negativních projevů chování nebo narušení jejich zdravého vývoje a zmírňovat a odstraňovat prííciny nebo důsledky rozvinutých poruch chování a negativních jevů (SVP, n.d.). Intervence se poskytují samotným žákům, školám i rodičům. Tým tvoří pedagogičtí pracovníci, speciální pedagogové a psychologové (Střediska výchovné péče, n.d.). Střediska jsou součástí sítě školských zařízení preventivně výchovné péče a školských zařízení pro výkon ústavní ochranné výchovy. Tvoří je jak ambulantní, tak internátní oddělení (SVP, n.d.)

\section{Pedagogicko-psychologická poradenská péče ve Velké Británii}

První typ poradenské péče v Anglii je školské poradenství, které v posledních letech získalo velikou podporu. Školní poradenství tzv. „counselling“ je jednou z nejčastějších forem psychologické terapie pro děti a mládež, která probíhá ve škole. Až $62 \%$ škol nabízí svým žákům poradenské služby (70 \% středních škol a 52 \% základní škol) a čísla stále narůstají. Služby jsou poskytovány kvalifikovanými odborníky, kteří se individuálně schází se studenty. Někteří mohou provádět i cílenou skupinovou práci. Poradenství je intervence, do které se mohou děti nebo studenti dobrovolně zapojit. Jejím cílem je překonávat jejich problémy v životě. Poradci nabízejí studentům možnost hovořit o jejich problémech a mohou pomoci v redukci distresu, se kterým se studenti setkávají v důsledku řady životních obtiží (např. šikana a jiné životní osobní či rodinné problémy). Dále podporuje studenty, kteří mají problém v rodinných či přátelských vztazích, a studenty, kteří mají potíže s ovládáním svých emocí. Mnoho žáků uvádí, že poradenství jim pomáhá se studiem, školní motivací a soustředěností. Školní poradenství má mnoho podob. Jednou z nich je preventivní intervence a krizová intervence. Dalšś z nich je účelné hodnocení aktuální situace a hledání cílů, kterých by chtěl student dosáhnout. Školní poradenství poskytuje také paralelní podporu studentům, kteří navštěvují jiné poradenství mimo školu a po ukončení poradenství mimo školu může student dále navštěvovat poradenství ve škole (GOV.UK, 2016).

Další typ poradenství a pomoci funguje pro studenty se speciálně vzdělávacími potřebami a určitým druhem postižení, v angličtině označovaný jako tzv. SEN (Special Educational Needs $=$ speciálně vzdělávací potřeby bez postižení) či SEND (Special Educational Needs and Disabilities $=$ speciálně vzdělávací potřeby a postižení). Služba je poskytována opět př́́mo ve škole. Rozlišujeme tedy studenty se SEND a SEN neboli studenty se speciálně vzdělávacími potřebami a postižením a studenty se speciálně vzdělávacími potřebami bez postižení. Co všechno patř́i mezi postižení a speciálně vzdělávací potřeby je možné vidět $\mathrm{v}$ tabulce č. 2 .

Pokud se objeví žák se speciálně vzdělávacími potřebami nebo žák se speciálně vzdělávacími potřebami a postižením, tak by konkrétní škola měla podniknout kroky k odstranění překážek ve vzdělávání a zavést vhodné vzdělávací metody. Při identifikaci dítěte, které má speciálně vzdělávací potřeby ve školním prostředí, spolupracuje tř́ídní učitel s oddělením pro žáky se speciálně vzdělávacími potřebami, které je př́mo na dané škole. Společně by pak měli provést analýzu potřeb žáka, která vychází z hodnocení učitelů, zkušeností žáka, zkušeností rodičů a ze srovnání s jeho vrstevníky. V některých př́ípadech 
Tabulka 2 Kategorie spadajici do postiženi a speciálnich vzdělávacích potřeb ve VB (Norfolk.gov.uk, n.d.)

\begin{tabular}{|l|l|}
\hline Postižení & Speciálně vzdělávací potřeby \\
\hline zdravotní postižení nebo chronická onemocnění & mírné řečové a komunikační obtíže \\
\hline smyslová postižení & obtiže v chování \\
\hline dlouhodobé poruchy učení & sociální a emoční problémy \\
\hline poruchy autistického spektra & lehké formy poruch autistického spektra \\
\hline závažné řečové poruchy & poruchy učení \\
\hline opožděný vývoj v předškolním věku & ADHD \\
\hline & jakékoliv potíže s učením \\
\hline
\end{tabular}

mohou být do procesu zapojeni i odborníci ze zdravotnických nebo sociálních služeb (GOV.UK, 2015).

Podpora je odlišná dle věku dítěte. $V$ předškolním věku (do pěti let věku dítěte) zahrnuje zdravotní prohlídku dítěte ve věku dvou až tří let, pomoc dítěti v prvním ročníku základní školy a poskytování speciálních pomůcek pro dítě s postižením. U dětí od 5 do 15 let je možné nastavit speciální vzdělávací program, využít extra pomoc od učitele nebo asistenta pedagoga, je tu možnost pracovat $\mathrm{v}$ malých skupinách, pomoc $\mathrm{v}$ účasti na trrídních aktivitách, pomoc v komunikaci s ostatními dětmi a v pomoci se sebeobsluhou a péči (toaleta, stravování apod.). U studentů starších 16 let se péče nastavuje na základě konkrétních možností jednotlivých škol (SEND, n.d.).

\section{Brighton Metropolitan College: zkušenost ze stáže}

Brighton Metropolitan College (dále MET) nabízí širokou škálu studijních oborů pro studenty každého věku. Obory mají široké zaměření a zahrnují obory pro studenty ve věku 16-19 let, vysokoškolské obory, učňovské obory, kurzy pro dospělé, kurzy pro zahraniční studenty a mnoho dalšího (např. obor kadeřnictví, sociální péče, obor elektrotechniky, podnikání, biomedicínské studium a kreativní obory). Celkem mají okolo 13000 studentů (MET, n.d.). První věc, která je na škole zajímavá, je propracovaný systém podpory, který je vidět na první pohled po celé škole. Škola využívá mnoho plakáti̊ a brožurek k propagování možnosti pomoci studentům při jejich vzdělávání, ale i zvládání osobních problémů. Plakáty visí po celé škole a brožury jsou studentům $k$ dispozici taktéž na mnoha místech. Brožury odkazují především na externí formu pomoci a týkají se všech možných témat. Jedná se hlavně o problémy spojené s alkoholem a drogami, podporu pro LGBT+ komunitu, rodinné problémy a jakékoliv jiné osobní problémy. Letáky pak studenty i pedagogy upozorňují na interní formu podpory, kterou škola nabízí. Kromě toho mnoho letáku slouží k seznámení s různými druhy poruch a postižení. Vysvětlují, o co se jedná, jaké jsou hlavní projevy a také popisují, jak s takovým člověkem pracovat. Dále také nabízejí vysvětlení různých psychologických pojmů např. attachment, na kterém vysvětlují důležitost vztahů mezi studenty.

Jakou psychologickou péči vlastně MET nabízí? MET má několik oddělení, která jsou zaměřena na podporu studentů. Oddělení jsou rozdělena pro studenty střední školy a pro 
univerzitní studenty. První z nich je podpora vzdělávání pro studenty se speciálně vzdělávacími potřebami a postižením (SEN a SEND). Toto oddělení škola nazývá Additional Learning Support. Tato podpora funguje podobně jako pedagogicko-psychologické poradny a speciálně pedagogická centra $\mathrm{v}$ České republice s tím rozdílem, že sídlí přímo ve škole. Oddělení podporuje studenty s řadou poruch učení nebo s různými druhy postižení, stejně jako je uvedeno v tabulce č. 2. (ALS, n.d.). Pro výraznou podporu škola potřebuje potvrzenou diagnózu externím odborníkem. V rámci nižší podpory ji škola nevyžaduje. Oddělení společně se studentem (př́ípadně s rodiči) stanoví jasná pravidla a hranice studentovy podpory při vzdělávání. Dalo by se říct, že se jedná o podobnou záležitost, jakou jsou podpůrná opatření v českém poradenství. Podobné jsou i možnosti podpory. Škola je schopna zajistit výuku v malých skupinách či výuku 1 : 1, což zajišt'ují speciální učitelé. Také je možnost využít osobního asistenta, který studentovi pomáhá ve výuce, ale i mimo ni. Mezi ně se řadí i asistent, který neslyšícím překládá výuku do anglického znakového jazyka. Je též možnost vypůjčení vybavení či podpůrné technologie. Co se týče samotné výuky, může oddělení navrhnout změnu učebních osnov na míru studentovi a přizpůsobit výukové materiály. Na škole také fungují tzv. zapisovači poznámek. Student může docházet na zkrácené vyučování nebo může mít pozměněnou formu zkoušek. Zkoušky bývají uzpůsobeny možnostem studenta, dále je př́iležitost využít delšího času na zpracování úkolů, použít sluchátka pro odhlučnění prostředí, zkoušku vykonat v tiché místnosti a mnoho dalšího. Předností toho oddělení jsou kvalitně zpracované materiály o jednotlivých postiženích, které informují učitele, jak s takovými studenty pracovat. Oddělení nabízí i kurzy pro učitele. Samožrejmě mají i brožury pro studenty, rodiče a učitele, které stručně a jasně popisují, jaké služby oddělení nabízí (ALS, n.d.).

Druhým oddělením je tzv. counselling neboli pastorační poradenství a psychologické poradenství, což v českém poradenství naplňuje školní psycholog. Pastorační poradenství nabízí speciální podporu, jak nejlépe využít svůj čas na vysoké škole. Mentoři pomáhají s př́padnými problémy, které mohou mít vliv na úspěšnost a spokojenost na škole. Studenti mohou mluvit o všem, co je trápí ve škole či mimo ni. Pokud jsou problémy závažnější, mohou mentoři studenta odkázat na psychologické poradenství ve škole či mimo ni. Psychologické poradenství nabízí pomoc se závažným stresem, úzkostí, depresemi, s poruchami spánku, př́ijmu potravy nebo jakýmkoliv jiným utrpením či traumatem. Obě poradenství fungují na principu individuální konzultace přímo ve škole. V př́ípadě potřeby může oddělení navrhnout další poradenské či zdravotnické služby nebo zajistit komunikaci s rodiči, učiteli či jinými zaměstnanci školy (Pastoral support, n.d.).

Další oddělení zajišt'uje kariérové poradenství a potřebné informace $\mathrm{k}$ budoucímu povolání, což v českém poradenství zajišt'uje přímo ve škole výchovný poradce nebo v pedagogicko-psychologické poradně psycholog. Jiné oddělení se zaměřuje na bezpečnost studentů a soustředí se na oblasti diskriminace, šikany, prevence, bezpečnost na internetu a sociálních sítích a na samotné zdraví studentů. V České republice by tuto funkci měl zajišt'ovat metodik prevence (Student services \& support, n.d.).

\section{Shrnutí}

Pedagogicko-psychologická poradenská péče funguje v České republice a Velké Británii velmi podobně. Obě země nabízejí podobné možnosti, jak podpořit studenty. 
Jedním z rozdílů je, že ve Velké Británii mají celý systém péče přímo ve škole. Naopak u nás mají pedagogicko-psychologické poradny a speciálně pedagogická centra na starosti více škol. Komplexní péče na jednom místě nabízí ucelenější pohled na situaci a možnost dlouhodobější a aktivnější vzájemné spolupráce. Vzhledem k velikosti českých škol je centralizovaná péče pravděpodobně výhodou a jistotou pro všechny školy bez ohledu na vnitřní možnosti školy. Dvě různé formy péče vně i uvnitř školy mohou poskytnout více pohledů na situaci, a studenti tak mohou hledat pomoc uvnitř i vně školy.

Druhým rozdílem je kvalitní psychologická péče tzv. counselling ve Velké Británii, která klade veliký důraz na tento druh pomoci. Bohužel v českých školách je tato péče stále velmi podceňovaná a často nedostupná. Na mnoha českých školách stále chybí školní psycholog, který by tuto péči zajišt'oval. Studenti tak mají omezené možnosti, kam se $\mathrm{v}$ př́ipadě potřeby obrátit.

\section{LITERATURA}

ALS: Additional Learning Support for 16+ college students: Helping you make the most of your time at college. (n.d.). In GBMC.AC.UK. [Vyhledáno 5. 1. 2020 na https://www.gbmc.ac.uk/student-support/student services/additional-learning-support].

Family Lives: What are special educational needs. (n.d.). In Family lives. [Vyhledáno 4. 1. 2020 na https://www .familylives.org.uk/advice/your-family/special-educational-needs/what-are-special-educational-needs/].

Geisslerová, E. (2012). Mit přehled: prưvodce informačními a poradenskými službami pro mládež v $\check{C}$. Praha: Národní institut dětí a mládeže Ministerstva školství, mládeže a tělovýchovy.

GOV.UK: Counselling in schools: a blueprint for the future: Departmental advice for school leaders and counsellors. (2016). In Gov.uk. [Vyhledáno 4. 1. 2020 na https://www.gov.uk/government/publications /counselling-in-schools]

GOV.UK: Special educational needs and disability code of practice: 0 to 25 years: Statutory guidance for organisations which work with and support children and young people who have special educational needs or disabilities. (2015). In Gov.uk. [Vyhledáno 4. 1. 2020 na https://assets.publishing.service.gov.uk/government /uploads/system/uploads/attachment_data/file/398815/SEND_Code_of_Practice_January_2015.pdf]

Hlad’o, P. (2012). Profesni orientace adolescentů: poznatky z teorii a výzkumů. Brno: Konvoj.

Children with special educational needs and disabilities (SEND). (n.d.). In Gov.uk. [Vyhledáno 4.1.2020 na https://www.gov.uk/children-with-special-educational-needs/special-educational-needs-support].

Institut pedagogicko-psychologického poradenství české republiky (IPPP ČR). (n.d.). In NÚV-Národní ústav pro vzdělávání. Praha. [Vyhledáno 2. 1. 2020 na http://www.nuv.cz/vse-o-nuv/ippp-cr].

Jedlička, R., Kot’a, J., \& Slavík, J. (2018). Pedagogická psychologie pro učitele: psychologie ve výchově a vzdělávání. Praha: Grada.

Kohoutek, R. (1998). Historie pedagogicko-psychologického poradenství. Pedagogická Orientace: Vědecký Časopis České Pedagogické Společnosti, 1998(3), 30-45.

Knotová, D. (2014). Školni poradenství. Praha: Grada.

Krejčová, L., Hladíková, Z., Šemberová, K., \& Balharová, K. (2018). Specifické poruchy učení: dyslexie, dysgrafie, dysortografie. Brno: Edika.

MET: About the MET: Why the MET? (n.d.). In GBMC.AC.UK. [Vyhledáno 5. 1. 2020 na https://www.gbmc .ac.uk/about-the-met].

Michalík, J. a kol. (2013). Speciálněpedagogické centrum: Informační brožura o činnosti speciálněpedagogických center. Olomouc: Univerzita Palackého v Olomouci.

Norfolk.gov.uk.: Difference between SEN and disabilities. (n.d.) In Norfolk.gov.uk. [Vyhledáno 19.10.2020 na https://www.norfolk.gov.uk/children-and-families/send-local-offer/about-the-local-offer/the-difference -between-sen-and-disabilities].

O nás. (n.d.). In NÚV - Národní ústav pro vzdělávání. Praha. [Vyhledáno 2.1.2020 na http://www.nuv.cz /vse-o-nuv]. 
Pastoral support: Pastoral support \& mental well-being for higher education students. (n.d.). In GBMC.AC.UK. [Vyhledáno 5.1.2020 na https://www.gbmc.ac.uk/pastoral-support-he]

PPP 9: Činnost poradny. (n.d.). In PPP9. [Vyhledáno 4. 1. 2020 na https://ppp9.cz/cinnost-poradny/].

Speciálně pedagogická centra (2018). In Ministerstvo školstvi, mládeže a tělovýchovy. [Vyhledáno 8. 10. 2020 na https://www.msmt.cz/vzdelavani/socialni-programy/specialne-pedagogicka-centra]

Školní poradenské pracoviště. (2018). In Inkluze v praxi. Praha: Národní institut pro další vzdělávání. [Vyhledáno 2. 1. 2020 na http://www.inkluzevpraxi.cz/kategorie-reditel/1149-povinnosti-skolniho-poradenskeho-pracoviste].

Školská poradenská zařízení (ŠPZ). (n.d.). In NÚV - Národní ústav pro vzdělávání. [Vyhledáno 2. 1. 2020 na http://www.nuv.cz/t/pedagogicko-psychologicke-poradenstvi/skolska-poradenska-zarizeni].

Střediska výchovné péče. (n.d.). In Ministerstvo školství, mládeže a tělovýchovy. [Vyhledáno 3. 1. 2020 na http:// www.msmt.cz/vzdelavani/socialni-programy/strediska-vychovne-pece]

Střediska výchovné péče (SVP). (n.d.). In Národní ústav pro vzdélávání. [Vyhledáno 3. 1.2020 na http://www .nuv.cz/t/pedagogicko-psychologicke-poradenstvi/strediska-vychovne-pece].

Student services \& support: A supportive environment. (n.d.). In GBMC.AC.UK. [Vyhledáno 5. 1. 2020 na https://www.gbmc.ac.uk/student-support].

Vyhláška č. 197/2016 Sb. o poskytování poradenských služeb ve školách a školských poradenských zařizeních, ve zněni pozdějšich predpisư, a některé dalši vyhlášky. (2016). Ministerstvo školství, mládeže a tělovýchovy.

Zapletalová, J. (n.d.). Školní poradenská pracoviště (ŠPP). In Národni ústav pro vzdělávání. Praha. [Vyhledáno 2. 1. $2020 \mathrm{na} \mathrm{http://www.nuv.cz/t/pedagogicko-psychologicke-poradenstvi/skolni-poradenska-pracoviste].}$

Mgr. Tereza Kolečková, Univerzita Karlova, Filozofická fakulta, katedra psychologie, email: koleckova.tereza@seznam.cz 